\title{
PENGARUH INTENSITAS MENONTON VIDEO YOUTUBE DAN KREDIBILITAS BEAUTY VLOGGER TERHADAP KEPUTUSAN PEMBELIAN \\ (Studi Channel Youtube Suhay Salim Video 'Wardah InstaPerfect Review Tutorial Swatches')
}

\author{
Via Carviola Ramdhini ${ }^{1 *}$, Ahmad Fatoni ${ }^{2}$ \\ ${ }^{1,2}$ Fakultas Ilmu Komunikasi Universitas Gunadarma \\ J1. Margonda Raya No. 100, Depok 16424, Jawa Barat \\ * Penulis korespondensi; Email: ${ }^{1}$ viaramdhini@gmail.com, ${ }^{2}$ ahmad_fatoni@ staff.gunadarma.ac.id
}

\begin{abstract}
ABSTRAK
Penelitian ini bertujuan untuk mengukur dan menganalisis pengaruh intensitas menonton video Youtube dan kredibilitas beauty vlogger terhadap keputusan pembelian. Jenis penelitian yang digunakan adalah kuantitatif, dengan metode survei kuatitatif yaitu menyebarkan kuesioner dengan subjeknya adalah viewers atau penonton Youtube Suhay Salim pada salah satu videonya. Menggunakan model SR, teori intensitas menonton dan teori kredibilitas sumber. Penentuan ukuran sampel ini menggunakan rumus Yamane dengan tingkat kesalahan 5\% sehingga memperoleh jumlah responden 400 sesuai dengan kriteria responden pada penelitian ini. Berdasarkan hasil uji hipotesis yaitu $\mathrm{T}$ dan uji $\mathrm{F}$ hasil menunjukkan variabel intensitas menonton video Youtube dan kredibilitsas beauty vlogger berpengaruh positif terhadap keputusan pembelian secara parsial dan simultan. Berdasarkan hasil korelasi menunjukkan derajat hubungan antara intensitas menonton video Youtube dan kredibilitas beauty vlogger merupakan kategori korelasi Kuat. Dengan demikian adanya pengaruh yang positif dan samasama memiliki hubungan yang cukup kuat antara intensitas menonton video Youtube dan kredibilitas beauty vlogger terhadap keputusan pembelian.
\end{abstract}

Kata kunci: Intensitas Menonton, Kredibilitas Beauty Vlogger, Keputusan Pembelian, Youtube.

\begin{abstract}
This research aims to measure and analyze how the intensity of watching Youtube videos impact and the credibility of beauty vloggers towards purchasing decisions. This study aims to determine and analyze the effect of the intensity of watching Youtube videos and the credibility of beauty vloggers on purchasing decisions. This type of research is quantitative, with a quantitative survey method that is distributing questionnaires with the subject are viewers or Youtube viewers Suhay Salim on one of the videos. Using the SR model, the watch intensity theory and the source credibility theory. The determination of this sample size uses the Yamane formula with an error rate of $5 \%$ so that the number of respondents is 400 according to the criteria of the respondents in this study. Based on the results of the hypothesis test that is $T$ and $F$ test results show variable intensity watching Youtube videos and the credibility of beauty vlogger have a positive effect towards purchasing decisions partially and simultaneously. Based on the results of the correlation shows the degree of relationship between the intensity of watching Youtube videos and and the credibility of beauty vlogger a strong. Thus, a positive impact and an equally strong enough relation between the intensity of watching Youtube videos and the credibility of the beauty vlogger towards purchasing decisions.
\end{abstract}

Keywords: Intensity Watching, Credibility of Beauty Vlogger, Buying Decisions, Youtube.

\section{PENDAHULUAN}

Youtube adalah salah satu new media yang dijadikan sebagai tempat memasarkan sebuah produk, dengan tujuan untuk mempengaruhi calon konsumen dalam pembeliannya. Dengan adanya komunikasi pemasaran sebagai kegiatan berkomunikasi yang mengarah pada konsumen, dapat memberikan pengetahuan baru dan informasi mengenai produk dengan menggunakan media, sehingga terjadi perubahan sikap dan tindakan yang diambil oleh konsumen untuk membeli.
Dalam beberapa tahun terakhir, fenomena beauty vlogger telah menjadi populer di kalangan milenium. Sebagai pengguna Youtube, dapat dilihat saat ini banyak orang berlomba-lomba untuk berbagi passion nya di bidang kosmetik dan kecantikan, dengan memberi ulasan tentang produk kecantikan, hingga memberikan tutorial tentang cara menggunakan produk kecantikan. Menjadi beauty vlogger kini semakin menjanjikan. Beberapa perempuan yang ingin membeli produk kecantikan, umumnya melihat review dari beauty vlogger terlebih dahulu dan beauty vlogger juga dapat penghasilan yang fantastis dari konten yang dibuatnya. 
Dengan intensitas menonton, dapat dipahami sebagai suatu kekuatan yang mendukung suatu pendapat atau suatu sikap individu dalam menanggapi isi pesan yang disampaikan dari video Youtube, seperti dalam membeli suatu produk kosmetik, konsumen akan membandingkan antara produk yang satu dengan produk yang lainnya dan akan lebih banyak memberikan perhatian pada produk yang memberikan manfaat. Sehingga dengan intensitas menonton video Youtube beauty vlogger, dapat diukur tingkat perhatian dan penghayatan individu dalam menonton video tersebut dengan frekuensi dan durasi yang mereka gunakan sebelum memutuskan untuk membeli produk.

Selain intensitas menonton, kredibilitas beauty vlogger juga merupakan aspek yang dapat mempengaruhi keputusan pembelian. Seorang beauty vlogger dengan viewers banyak harus memiliki karakter dan kepribadian yang baik. Salah satunya, memiliki kredibilitas yang didukung faktor keahlian, sifat dapat dipercaya dan adanya kesukaan pada dirinya sebagai seorang yang menyampaikan informasi mengenai sebuah produk kecantikan. Selain memberikan pengaruh, beauty vlogger juga dapat mengubah perilaku perempuan di Indonesia, yang selalu ingin tampil cantik luar dan dalam.

Intensitas menonton dan kredibilitas beauty vlogger menjadi sarana penting bagi konsumen untuk mendapatkan informasi mengenai suatu produk kecantikan. Semakin tinggi intensitas menonton video Youtube dan kredibilitas beauty vlogger, maka akan menghasilkan keputusan pembelian yang tinggi. Keputusan pembelian yang dilakukan konsumen melibatkan keyakinan konsumen pada suatu produk sehingga timbul rasa percaya diri atas kebenaran tindakan yang diambil. Dalam perilaku konsumen banyak ditemukan faktor yang mempengaruhi keputusan pembelian konsumen, faktor- faktor tersebut adalah merek, harga, kualitas, promosi dan sebagainya. Faktor yang mempengaruhi keputusan pembelian konsumen akan suatu produk dapat berasal dari dalam diri konsumen maupun berasal dari luar diri konsumen (Kusumastuti, 2011).

Pemilihan Suhay Salim sebagai salah satu beauty vlogger yang penulis pilih karena dalam video di Youtube mengenai review Wardah InstaPerfect, channel milik Suhay Salim yang mendapat viewers terbanyak yaitu 1,3 juta penonton (Youtube.com, diakses Mei 2019). Selain itu, Suhay Salim sendiri merupakan beauty vlogger yang saat ini menjadi idola bagi para remaja perempuan. Hal paling unik yang membedakan Suhay Salim dengan beauty vlogger lainnya adalah gaya bicaranya yang to the point atau terus terang namun terdengar kocak atau lucu, sehingga individu yang menontonnya tidak bosan dengan kelucuannya pada saat memberikan ulasan dan tutorial mengenai make up.

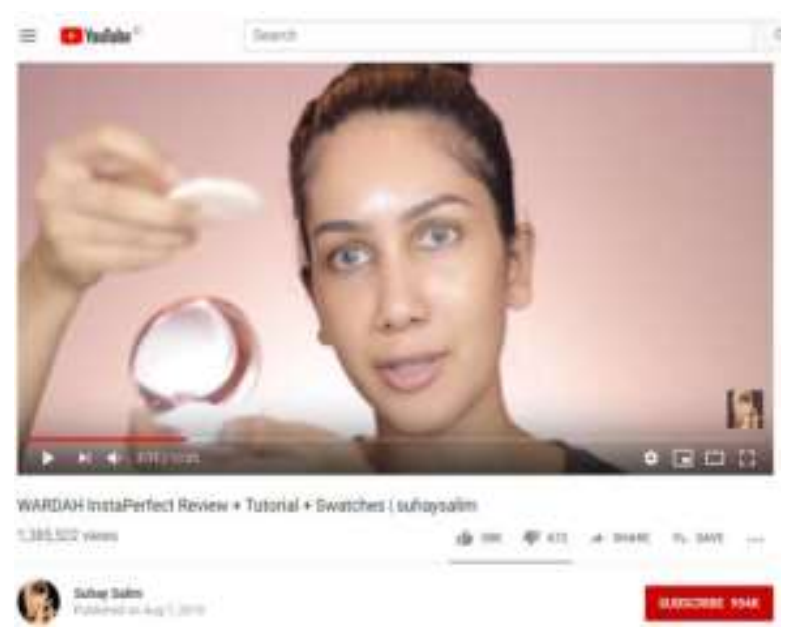

Gambar 1. Salah satu beauty vlogger

Produk kosmetik Wardah adalah salah satu produk kosmetik yang memiliki banyak peminat, hal ini dibuktikan dengan banyaknya pengharagaan yang diraih oleh Wardah, yaitu Halal Award pada tahun 2011, serta The 1st Indonesia Original Brand tahun 2012 versi Majalah SWA. Wardah juga berhasil menjadi brand lokal terbesar di Indonesia. Selain itu pada website top brand, Wardah menduduki posisi top brand No.1 dalam kategori perawatan pribadi di tahun 2019 dengan berbagai jenis produk kosmetik seperti, lipstik, eyeliner serta BB Cream.

\section{KERANGKA TEORI}

\subsection{Landasan Konseptual}

\subsubsection{New Media atau Media Baru}

Media Baru atau New media merupakan istilah yang digunakan untuk semua media komunikasi yang berlatar belakang teknologi komunikasi dan informasi. Contoh media yang merepresentasikan media baru adalah internet. Program televisi, film, majalah, buku, surat kabar dan jenis media cetak lain tidak termasuk media baru. Istilah media baru telah digunakan sejak tahun 1960-an dan telah mencangkup seperangkat teknologi komunikasi terpaan yang semakin berkembang dan beragam (McQuail, 2011). 


\subsection{Komunikasi Pemasaran}

Komunikasi Pemasaran, bermula dari pemenuhan akan kebutuhan manusia kemudian menungkat menjadi keinginan manusia. Proses pemenuhan kebutuhan dan keinginan manusia tersebut yang menjadi konsep utama pemasaran. Penggabungan kajian komunikasi dan pemasaran telah menghasilkan kajian baru yang disebut dengan komunikasi pemasaran salah satunya dengan adanya promosi yang termasuk kedalam bauran pemasaran (Shimp, 2003).

\subsection{Youtube}

Youtube merupakan salah satu media sosial yang banyak digemari oleh masyarakat. Pemanfaatan Youtube dapat digunakan dengan mengunggah videovideo yang menunjukkan bakat, hobi, atau pun kegiatan yang dapat memberikan hal dan informasi positif bagi pengguna lainnya (Zarella, 2010)

\subsection{Intensitas Menonton Video Youtube}

Intensitas menonton diartikan bukan hanya melihat sebuah tayangan namun juga secara intens memperhatikannya. Menurut Sari dalam menentukan intensitas seseorang dalam mengakses media dapat ditentukan dengan: penggunaan media, frekuensi penggunaan media, durasi seseorang berinteraksi dengan media (Wibawa, 2018).

\subsubsection{Beauty Vlogger}

Beauty vlogger merupakan sosok yang memiliki keahlian atau konsentrasi dalam bidang kecantikan yang memberikan informasi terkait produk-produk kecantikan yang telah mereka gunakan atau dengan kata lain untuk beauty vlogger memberikan pengalaman mereka dalam menggunakan produk kecantikan. Beauty vlogger bersifat objektif terhadap beragam produk yang mereka gunakan sehingga informasi yang disampaikan pun dapat berupa positif maupun negatif dari produk yang telah digunakan (Febriana, 2018).

\subsubsection{Kredibilitas Beauty Vlogger}

Seorang beauty vlogger dengan endorser atau brand ambassador memiliki kekuatan yang sama untuk mempengaruhi pemikiran seseorang sebagai pembicara yang dapat mengantarkan sebuah pesan menjadi informasi yang berguna bagi yang melihatnya. Maka dari itu seorang beauty vlogger harus memiliki karakteristik yang baik seperti kredibilitas yang dimilikinya untuk dapat mengetahui keahlian pada pengetahuannya tentang produk yang dipakainya dan memiliki kemampuan untuk memberikan keyakinan atau kepercayaan pada penontonnya akan suatu produk

\subsection{Keputusan Pembelian}

Keputusan pembelian konsumen adalah keputusan konsumen mengenai preferensi merek- merek yang ada di dalam kumpulan pilihan. Proses yang digunakan konsumen untuk mengambil keputusan pembelian yang terdiri atas lima tahap (Kotler dan Keller, 2009): (1) Pengenalan masalah, yaitu pembeli menyadari suatu masalah atau kebutuhan yang dipicu oleh rangsangan internal atau eksternal. (2) Pencarian informasi: konsumen yang telah tertarik mungkin akan mencari lebih banyak informasi. (3) Evaluasi Alternatif: suatu tahap dalam proses pengambilan keputusan pembelian di mana konsumen menggunakan informasi untuk mengevaluasi merek-merek alternative dalam susunan pilihan. Konsumen akan memberikan perhatian yang besar pada produk yang mampu memenuhi kebutuhannya. (4) Keputusan pembelian, merupakan bagian dari proses pengambilan keputusan pembelian kepada konsumen yang membeli produk yang paling mereka sukai. (5) Perilaku pasca pembelian: proses pengambilan keputusan pembelian di mana konsumen mengambil tindakan lebih lanjut setelah membeli berdasarkan kepuasan dan ketidakpuasan yang mereka rasakan.

\subsection{Landasan Teori Model SR}

Model Stimulus Response $(\mathrm{S}-\mathrm{R})$ adalah model komunikasi paling dasar. Model ini dipengaruhi oleh disiplin psikologi, khususnya yang beraliran behavioristic. Model tersebut menggambarkan hubungan stimulus - respons. Model S-R mengabaikan komunikasi sebagai suatu proses, khususnya yang berkenaan dengan faktor manusia. Secara implisit ada asumsi dalam model S-R ini bahwa perilaku (respons) manusia dapat diramalkan. Ringkasnya, komunikasi dianggap statis, manusia dianggap berprilaku karena kekuatan dari luar (stimulus), bukan berdasarkan kehendak, keinginan, atau kemampuan bebasnya (Mulyana, 2005).

\subsection{Teori Intensitas Menonton}

Berdasarkan aspek-aspek intensitas oleh Azjen (dalam Setiawan, 2005) di atas, maka untuk mengukur intensitas menonton video Youtube dengan empat indikator, yaitu (1) Perhatian adalah tersitanya perhatian maupun waktu dan tenaga individu untuk menonton video tersebut yang telah disajikan. (2) 
Penghayatan yaitu pemahaman dan penyerapan terhadap informasi yang diharapkan, kemudian informasi tersebut dipahami, dinikmati dan disimpan sebagai pengetahuan yang baru. (3) Durasi yaitu lamanya selang waktu yang dibutuhkan individu untuk menonton sebuah tayangan TouYube. (4) Frekuensi, merupakan banyaknya pengulangan perilaku yang menjadi target.

\subsection{Teori Kredibilitas Sumber}

Penelitian ini menggunakan teori yang dikemukakan oleh Hovland, Janis dan Kelley yaitu Teori Kredibilitas Sumber (Source Credibility Theory). Asumsi dasar dari teori ini adalah menyatakan bahwa seseorang dimungkinkan lebih mudah dipersuasi jika sumber-sumber persuasinya cukup kredibel. "High credibility sources had a substantially greater immediate effect on the audience's opinions than low credibility sources" (Hovland, 2007). Hovland menggambarkan peranan kredibilitas dalam proses penerimaan pesan dengan mengemukakan bahwa para ahli akan lebih persuasif dibandingka dengan bukan ahli. Suatu pesan persuasif akan lebih efektif apabila kita mengetahui bahwa penyampai pesan adalah orang yang ahli di bidangnya (Azwar, 2011). Terdapat tiga komponen kredibilitas pendukung selebriti (Ohanian, 1990) yaitu: Keahlian (Expertise), Dapat dipercaya (Trustworthiness) dan Daya Tarik (Attractiveness).

\subsection{Model Penelitian}

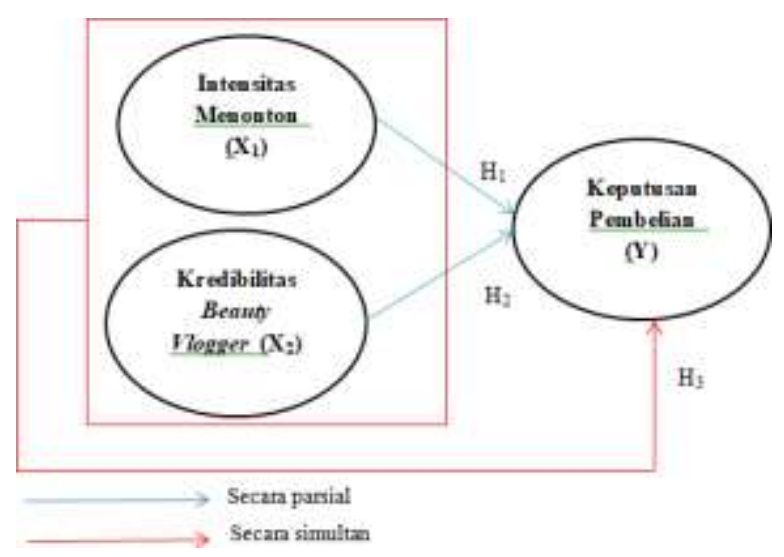

Gambar 2. Model Penelitian

\subsection{Hipotesis}

$\mathrm{Ho}_{1}$ : Tidak ada pengaruh intensitas menonton video Youtube terhadap keputusan pembelian

$\mathrm{Ha}_{1}$ : Adanya pengaruh intensitas menonton video Youtube terhadap keputusan pembelian
$\mathrm{Ho}_{2}$ : Tidak ada pengaruh kredibilitas beauty vlogger terhadap keputusan pembelian

$\mathrm{Ha}_{2}$ : Adanya pengaruh kredibilitas beauty vlogger terhadap keputusan pembelian

$\mathrm{Ho}_{3}$ : Tidak ada pengaruh intensitas menonton video Youtube dan kredibilitas beauty vlogger terhadap keputusan pembelian

$\mathrm{Ha}_{3}$ : Adanya pengaruh intensitas menonton video Youtube dan kredibilitas beauty vlogger terhadap keputusan pembelian.

\section{METODOLOGI PENELITIAN}

Penelitian ini diklasifikasikan dalam penelitian kuantitatif desktiptif dengan menggunakan metode regresi linier berganda. Metode penelitian kuantitatif adalah metode penelitian sebagai metode yang berlandaskan pada filsafat positivisme metode yang digunakan untuk meneliti pada populasi atau sampel tertentu, teknik pengambilan sampel biasanya dilakukan dengan perhitungan teknik sampel tertentu yang sesuai pengumpulan data kuantitatif atau statistik dengan tujuan untuk menguji hipotesis yang telah ditetapkan (Sugiyono, 2008).

Penelitian ini dilaksanakan selama lima bulan pada periode bulan Maret hingga bulan Agustus 2019. Penelitian ini menggunakan Youtube channel beauty vlogger bernama Suhay Salim sebagai lokasi penelitian. Populasi dalam penelitin ini adalah viewers atau penonton video review oleh Suhay Salim mengenai Wardah InstaPerfect dan sudah membeli produk tersebut. Viewers atau penonton merupakan pelaku maupun penerima pesan melalui review pada produk Wardah InstaPrfect di Youtube dengan populasi sebesar 1,398 juta penonton. Berdasarkan perhitungan menggunakan rumus Yamane dengan tingkat kesalahan 5\%, sampel yang diperoleh sebesar 400 sampel. Teknik pengumpulan data menggunakan teknik kuesioner. Teknik pengukuran data menggunakan Skala Likert. Teknik analisis data dengan menggunakan Uji Asumsi Klasik, Analisis Regresi Linear Berganda, Uji Hipotesis dan Uji Koefisien Determinasi. Teknik validitas menggunakan korelasi product momen dengan pernyataan variabel $\mathrm{X}_{1}$ (Intensitas Menonton Video Youtube), $\mathrm{X}_{2}$ (Kredibilitas Beauty Vlogger) dan Y (Keputusan Pembelian) dinyatakan valid dengan $r$ hitung $>r$ tabel $(0,361)$ dan teknik reliabilitas menggunakan croanchbach alpha dengan hasil semua instrumen pernyataan dinyatakan reliable yaitu variabel $X_{1}$ dengan nilai Alpha Cronbach $0,814, \mathrm{X} 2$ dengan nilai 0,888 dan $\mathrm{Y}$ dengan nilai $0,815>0,06$. 


\section{HASIL DAN PEMBAHASAN}

Uji asumsi klasik berdasarkan hasil uji normalitas, uji multikolinieitas, uji heteroskedastisitas dan Uji Autokorelasi.

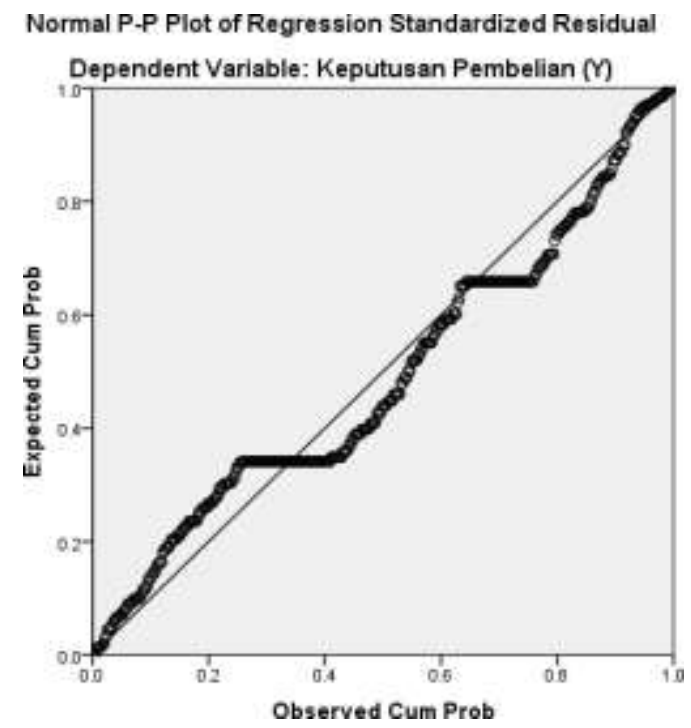

Gambar 3. Uji Normalitas

Uji normalitas berdasarkan grafik histogram mengikuti garis normal itu artinya model regresi berdistribusi normal.

Tabel 1. Uji Multikoliniearitas

\begin{tabular}{|c|c|c|c|c|c|c|c|}
\hline \multirow{3}{*}{ Model } & \multicolumn{3}{|c|}{ Unstandadized Unstandadized } & \multirow{3}{*}{$\mathrm{t}$} & \multirow{2}{*}{\multicolumn{3}{|c|}{$\begin{array}{cc}\text { Stg. Collinearity } \\
\text { Statistics }\end{array}$}} \\
\hline & \multicolumn{2}{|c|}{ Coefficiens } & Coefficiens & & & & \\
\hline & B & $\begin{array}{l}\text { Std. } \\
\text { Error }\end{array}$ & Beta & & & $\begin{array}{l}\text { Tole- } \\
\text { rance }\end{array}$ & VIF \\
\hline 1 (Constant) & 4.440 & .713 & & 6.231 & .000 & & \\
\hline Intensitas & .479 & .063 & .390 & 7.664 & .000 & .536 & 1.865 \\
\hline Menonton Video & & & & & & & \\
\hline You Tube (X1) & & & & & & & \\
\hline Kredibillitas & .202 & .030 & .340 & 6.687 & .000 & .536 & 1.865 \\
\hline $\begin{array}{l}\text { Beauty Vlogger } \\
\text { (X2) }\end{array}$ & & & & & & & \\
\hline
\end{tabular}

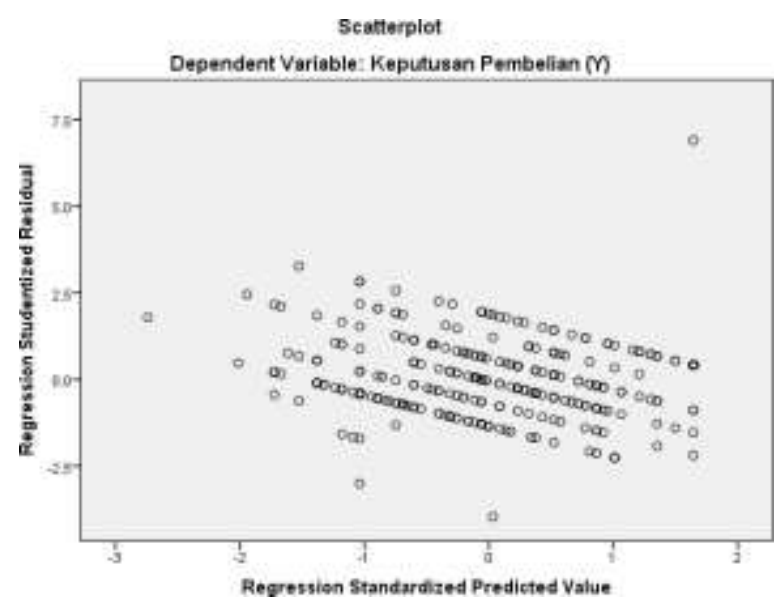

Gambar 4. Uji Heteroakedastisitas
Hasil nilai uji multikolinieritas yang didapat yaitu nilai tolerance $X_{1}$ dan $X_{2}(0,536)$ dan nilai VIF yaitu $1,865<10,00$ artinya tidak ada gejala multikolinieritas.

Hasil uji heteroskedasitisitas yaitu titik-titik data menyebar di atas dan di bawah atau di sekitar angka 0 , titik-titik data tidak mengumpul hanya di atas atau di bawah saja.

Tabel 2. Uji Autokorelasi

\begin{tabular}{lccccc}
\hline Model & $\mathrm{R}$ & $\begin{array}{c}\mathrm{R} \\
\text { Swuare }\end{array}$ & $\begin{array}{c}\text { Adjusted R } \\
\text { Square }\end{array}$ & $\begin{array}{c}\text { Std. Error of } \\
\text { the Estimate }\end{array}$ & $\begin{array}{c}\text { Durbin- } \\
\text { Watson }\end{array}$ \\
\hline 1 & $.670^{\mathrm{a}}$ & .449 & .446 & 1.548 & 1.977 \\
\hline a. & Predictors: (Constant, Kredibilitas & Beauty (X2), Intensitas \\
& Menonton Video YoutTube (A1) \\
b. Dependent Variable: Keputusan Pembelian (Y).
\end{tabular}

Hasil Uji Autokorelasi jumlah variabel independen 2 $(\mathrm{k}=2)$, maka di tabel DurbinWatson akan didapat nilai du sebesar 1,840. Sehingga 1,840 (du) $<1,977$ (DW) $<2.16(4-\mathrm{du}=4-1,840)$, maka dapat disimpulkan bahwa tidak terdapat autokorelasi.

Tabel 3. Hasil Analisis Regresi Berganda

\begin{tabular}{|c|c|c|c|c|c|c|}
\hline \multicolumn{7}{|c|}{ Coefficients $^{\mathrm{a}}$} \\
\hline \multirow{3}{*}{\multicolumn{2}{|c|}{ Model }} & \multicolumn{3}{|c|}{ Unstandardized Unstandardized } & \multirow{3}{*}{$\mathrm{t}$} & \multirow{3}{*}{ Sig. } \\
\hline & & \multicolumn{2}{|c|}{ Coefficients } & \multirow{2}{*}{$\begin{array}{c}\text { Coefficients } \\
\text { Beta }\end{array}$} & & \\
\hline & & B & $\begin{array}{l}\text { Std. } \\
\text { Error }\end{array}$ & & & \\
\hline & (Constant) & 4.440 & .713 & & 6.231 & .000 \\
\hline & Intensitas & .479 & .063 & .390 & 7.664 & .000 \\
\hline & Menonton & & & & & \\
\hline & Video You & & & & & \\
\hline & Tube (X1) & & & & & \\
\hline & Kredibillitas & .202 & .030 & .340 & 6.687 & .000 \\
\hline & $\begin{array}{l}\text { Beauty Vlogger } \\
\text { (X2) }\end{array}$ & & & & & \\
\hline
\end{tabular}

Berdasarkan hasil analisis regresi linier berganda, dapat Intensitas Menonton Video Youtube $\left(\mathrm{X}_{1}\right)$ sebesar 0.479 per satuan dan Kredibilitas Beauty Vlogger $\left(\mathrm{X}_{2}\right)$ sebesar 0.202 per satuan. Selain itu, diperoleh persamaan regresi sebagai berikut: $\mathrm{Y}=$ $4,440+0,479 X_{1}+0,202 X_{2}$. Persamaan regresi tersebut memiliki arti bahwa jika X1, dan X2 adalah nol, maka variabel $Y$ akan konstan sebesar 4,440. Apabila terjadi kenaikan $\mathrm{X}_{1}$ sebesar 5\% maka akan terjadi peningkatan Y sebesar 0,479. Apabila terjadi kenaikan $\mathrm{X}_{2}$ sebesar 5\% maka akan terjadi peningkatan $\mathrm{Y}$ sebesar 0,202. $\mathrm{T}_{\text {tabel }} \mathrm{n} 400$ dengan df: $400-2=398$ sebesar 1,965 .

Berdasarkan perhitungan tabel uji $\mathrm{t}$ adalah pada variabel $\mathrm{X}_{1}$ ( Intensitas Menonton Video Youtube) nilai thitung $7,664>t_{\text {tabel }} 1,965$ dan nilai sig $0,000<0,05$ 
angka tersebut menunjukkan bahwa $\mathrm{Ho}_{1}$ ditolak dan $\mathrm{Ha}_{1}$ diterima yang berarti terdapat pengaruh yang signifikan variabel $\mathrm{X}_{1}$ terhadap variabel $\mathrm{Y}$. Sedangkan pada variabel $\mathrm{X}_{2}$ (Kredibilitas Beauty Vlogger) nilai thitung $6,687>t_{\text {tabel }} 1,965$ dan nilai sig $0,000<0,05$ angka tersebut menunjukkan bahwa $\mathrm{Ho}_{2}$ ditolak dan $\mathrm{Ha}_{2}$ diterima yang berarti terdapat pengaruh dan signifikan variabel $\mathrm{X}_{2}$ terhadap $\mathrm{Y}$.

Tabel 4. Uji T (Parsial)

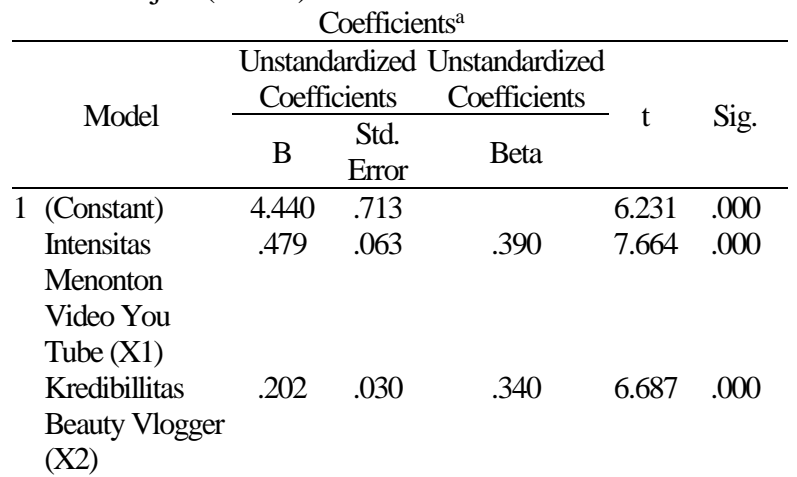

a. Dependent Variable: Keputusan Pembelian (Y)

Tabel 5. Hasil Uji F (Simultan)

\begin{tabular}{lrrrrr}
\multicolumn{6}{c}{ ANOVA $^{\mathrm{a}}$} \\
\hline \multicolumn{1}{c}{ Model } & \multicolumn{1}{c}{$\begin{array}{l}\text { Sum of } \\
\text { Squares }\end{array}$} & \multicolumn{1}{c}{ df } & \multicolumn{1}{c}{$\begin{array}{c}\text { Mean } \\
\text { Square }\end{array}$} & \multicolumn{1}{c}{ F } & Sig. \\
\hline 1 Regression & 773.856 & 2 & 386.928 & 262.569 & $.000^{\mathrm{b}}$ \\
Residual & 950.742 & 397 & 2.395 & & \\
Total & 1724.598 & 399 & & & \\
\hline
\end{tabular}

a. Dependent Variable: Keputusan Pembelian (Y)

b. Predictors: Constant), Kredibilitas Beauty Vlogger (X2), Intensitas Menonton Video You Tube (X1)

Pada tabel hasil uji $\mathrm{F}$ diketahui bahwa nilai $\mathrm{F}_{\text {hitung }}$ untuk Intensitas Menonton Video Youtube $\left(\mathrm{X}_{1}\right)$ dan Kredibilitas Beauty Vlogger $\left(\mathrm{X}_{2}\right)$ terhadap Keputusan Pembelian (Y) adalah 161,569 $>\mathrm{F}_{\text {tabel }}$ 6,90 dan nilai signifikan menunjukan $0.000<0,05$. Karena sig < 0,05 dan $\mathrm{F}_{\text {hitung }}>\mathrm{F}$ tabel, maka dapat disimpulkan bahwa $\mathrm{Ho}_{3}$ ditolak $\mathrm{Ha}_{3}$ diterima.

Untuk uji korelasi dan koefisien determinasi, pada penelitian ini nilai $\mathrm{R}=0,670$ dan koefisien determinasi ( $\mathrm{R}$ square) adalah sebesar 0,449. Angka tersebut menunjukkan pengertian bahwa pengaruh Intensitas Menonton Video Youtube dan Kredibilitas Beauty Vlogger terhadap keputusan pembelian adalah sebesar 44,9\% dengan kategori cukup kuat. Sementara sisanya sebesar $55,1 \%$ dipengaruhi oleh variabel lain yang tidak dimasukkan dalam penelitian ini.

Hasil penelitian ini sesuai dengan teori intensitas menonton, yang beranggapan bahwa intensitas menonton diartikan bukan hanya melihat sebuah tayangan namun juga secara intens memperhatikan- nya dan tidak lepas dari dorongan masing-masing individu untuk menikmati apa yang ditayangkan oleh media, sehingga adanya suatu terpaan dari media yang digunakannya secara intens.

Penelitian intensitas menonton oleh Azjen (dalam Setiawan, 2005) dalam penelitian ini terjadi ketika beauty vlogger (komunikator) membuat video mengenai produk Wardah InstaPerfect dengan memberikan ulasan atau komentar, tutorial atau cara menggunakannya dan mengaplikasikan beberapa produk yang dimasukkan ke Youtube, individu kemudian memperhatikan dan meluangkan waktunya untuk menonton. Sehingga, semakin tinggi intensitas menonton video Youtube maka, semakin tinggi keputusan pembeliannya.

Dalam teori kredibilitas sumber dari beauty vlogger itu sendiri, juga dapat berpengaruh terhadap keputusan pembelian. Penelitian kredibilitas beauty vlogger oleh Ohanian (1990) dimana Suhay Salim salah satu beauty vlogger sebagai komunikator yang mengulas produk baru dari Wardah yaitu Wardah InstaPerfect memiliki kredibilitas yang baik seperti tingkat keahliannya dalam pengetahuan, pengalaman dan kemampuannya mengenai produk Wardah, kemudian Suhay salim jujur dan tulus dalam memberikan ulasan atau review mengenai produk Wardah dan dipercayai dari pengalamannya berinteraksi dengan viewers melalui kolom komentar. Hasil make up produk Wardah InstaPerfect memiliki kesamaan dari apa yang telah disampaikan sehingga memiliki daya tarik bagi para viewers atau penontonnya.

Sesuai dengan model SR, stimulus yang didapatkan dari menonton video Youtube dan informasi yang disampaikan oleh beauty vlogger dapat direspon oleh individu dengan keputusannya untuk membeli produk Wardah InstaPerfect. Sehingga sesuai dengan teori apabila intensitas menonton video Youtube tinggi, maka viewers akan memiliki hasrat untuk memiliki produk Wardah dengan keputusannya yang mutlak. Namun sebaliknya jika semakin rendah hasrat untuk menonton video Youtube, akan semakin rendah munculnya keputusan pembelian.

Pada hasil koefisiean determinasi (R) menunjukkan pengaruh yang diberikan variabel bebas yaitu intensitas menonton video Youtube dan kredibilitas beauty vlogger terhadap variabel terikat yaitu keputusan pembelian sebesar $44,9 \%$, sedangkan sisanya sebesar 55,1\% dipengaruhi oleh variabel lain diluar variabel yang digunakan dalam penelitian ini. 


\section{PENUTUP}

\subsection{Kesimpulan}

Berdasarkan hasil dari analisis data dan pembahasan yang telah dilakukan, dapat diambil kesimpulan bahwa:

- Adanya pengaruh Intensitas menonton video Youtube terhadap keputusan pembelian secara parsial dengan $\mathrm{Ho}_{1}$ ditolak dan $\mathrm{Ha}_{1}$ diterima, sehingga menunjukan bahwa variabel $\mathrm{X}_{1}$ (Intensitas Menonton Video Youtube) berpengaruh positif terhadap variabel Y (Keputusan Pembelian).

- Adanya pengaruh kredibilitas beauty vlogger terhadap keputusan pembelian secara parsial dengan $\mathrm{Ho}_{2}$ ditolak dan $\mathrm{Ha}_{2}$ diterima, sehingga menunjukan bahwa variabel $\mathrm{X}_{2}$ (Kredibilitas Beauty Vlogger) berpengaruh positif terhadap variabel Y (Keputusan Pembelian).

- Adanya pengaruh intensitas menonton video Youtube dan Kredibilitas beauty vlogger secara bersama-sama. Keduanya memiliki pengaruh positif dan signifikan terhadap Keputusan pembelian dengan hasil uji koefisien determinasi, yang menyatakan bahwa hubungan antara Intensitas menonton video Youtube dan kredibilitas beauty vlogger terhadap Keputusan Pembelian sebesar $67 \%$ artinya memiliki hubungan yang kuat.

\subsection{Saran}

Berdasarkan kesimpulan diatas, dikemukakan beberapa saran yang dapat bermanfaat bagi perusahaan ataupun pihak lainnya. Adapun saran sebagai berikut:

1. Bagi beauty vlogger dapat meningkatkan keahliannya dalam membuat video mengenai make up dan produk-produk kecantikan, terutama produk yang baru dirilis oleh beberapa perusahaan lokal di Indonesia. Dengan memberikan ulasan yang jujur serta memberi tutorial yang mudah dan dipahami oleh viewers dengan karakter yang menarik, sehingga tidak mudah bosan untuk menontonnya.

2. Bagi perusahaan, hasil penelitian ini bisa dijadikan masukkan untuk kegiatan pemasaran produk demi meningkatkan keuntungan secara materi maupun non materi dan tidak merugikan konsumen. Selain brand ambassador mungkin menggunakan beauty vlogger yang mempunyai skill dapat dijadikan hal yang baru untuk Wardah mempromosikan produknya, dengan hasil yang maksimal dan dapat terus berkembang dengan cepat, karena melihat perkembangan Youtube saat ini yang banyak diminati oleh masyarakat.
3. Bagi peneliti selanjutnya disarankan agar dapat melakukan penelitian sejenis dengan menambahkan serta mengukur variabel lain seperti harga, citra merek, kualitas, dan isi konten agar dapat meningkatkan keputusan pembelian. Serta mencari teori pendukung lainnya yang memang dikhususkan untuk mengukur variabel keputusan pembelian, dan juga mengubah subjek yang akan diteliti, sehingga menjadi penelitian yang lebih baik lagi yang dapat dijadikan acuan untuk perusahaan.

\section{DAFTAR PUSTAKA}

Febriana, Mitha. 2018. Pengaruh Online Consumer Review Oleh Beauty Vlogger Terhadap Keputusan Pembelian: Survei Pada Mahasiswi Fakultas Ilmu Administrasi Universitas Brawijaya Angkatan 2014/2015 Dan 2015/2016 Yang Membeli dan Menggunakan Purbasari Matte Lipstick. Universitas Brawijaya. Jurnal Administrasi Bisnis. Vol.58, No,1.

Hovland, Carl L. 2007. Definisi Komunikasi. Jakarta: PT. Raja Grafindo Persada. Kottler dan Keller. 2009. Manajemen Pemasaran. Jilid 1, Edisi 13, Jakarta: Erlangga Kusumastuti, Y.I. 2011. Komunikasi Bisnis. Bogor: IPB Press.

McQuail, Denis. 2011. Teori Komunikasi Massa McQuail. Edisi 6, Buku 1. Jakarta: Salemba Humanika.

Mulyana, Deddy. 2005. Ilmu Komunikasi Suatu Pengantar. Bandung: PT Remaja Rosdakarya.

Ohanian, Roobina. 1990. Construction and Validation of Scale to Measure Celebrity Endorser Perceived Expertise, Trustworthness, and Attractiviness. Journal of Advertising. ABI/INFORM Research.

Setiawan, B. 2005. Hubungan Antara Intensitas Menonton Tayangan Misteri Dengan Tingkat Kecemasan Pada Remaja Di SMPN 4 Batang. Skripsi. Jogjakarta: Universitas Ahmad Dahlan.

Shimp. 2003. Periklanan Promosi Aspek Tambahan Komunikasi Terpadu, Erlangga, Jakarta. Sugiyono. 2008. Metode Penelitian Kuantitatif Kualitatif dan $R \& D$. Bandung: Alfabeta.

Wibawa, Michael Aryatama. 2018. Pengaruh Intensitas Menonton Channel Youtube Reza Oktovian dan Pengawasan Orang Tua terhadap Perilaku Agresif yang dilakukan Remaja Sekolah Menengah Pertama. Universitas Padjajaran, Jurnal Interaksi Online. Vol.6, No.3.

Zarella, D. 2010. The Social Media Marketing Book. Jakarta: PT Serambi Ilmu Semesta Anggota IKAPI. 